\title{
Stable isotope method reveals the role of abiotic source of carbon dioxide efflux from geothermally warmed soil in southern Iceland
}

\author{
MARJA MALJANEN' ${ }^{\text {, HELI YLI-MOIJALA }}{ }^{1}$, BJARNI D. SIGURDSSON², \\ CHRISTINA BIASI ${ }^{1}$ \\ ${ }^{1}$ University of Eastern Finland, Department of Environmental and Biological Sciences, P.O.Box 1627, Finland \\ ${ }^{2}$ Agricultural University of Iceland, Keldnaholt, 112 Reykjavik, Iceland \\ Correspondence to: Marja Maljanen (marja.maljanen@uef.fi)
}

\begin{abstract}
Natural temperature gradients which can appear within geothermal areas have been used to study effects of warming on carbon dioxide $\left(\mathrm{CO}_{2}\right)$ fluxes from soils and thus to study climate feedbacks on natural unwarmed ecosystems. However, at least among ecologists, it is less known that geothermal areas also release abiotic $\mathrm{CO}_{2}$ and thus confound the interpretations of temperature dependencies of respiratory fluxes. Carbon dioxide efflux and its $\delta^{13} \mathrm{C}$ values (which differ between biotic and abiotic $\mathrm{CO}_{2}$ ) were thus measured using the static chamber method in a Sitka spruce forest floor in Iceland in 2014 and 2016, along a natural geothermal soil temperature $\left(\mathrm{T}_{\mathrm{s}}\right)$ gradient, which at $10 \mathrm{~cm}$ depth ranged from the ambient temperature up to $65^{\circ} \mathrm{C}$ warming. In 2014 , soil $\mathrm{CO}_{2}$ efflux increased steadily $\left(260-3900 \mathrm{mg} \mathrm{CO}_{2} \mathrm{~m}^{-2} \mathrm{~h}^{-1}\right)$ with increasing $\mathrm{T}_{\mathrm{s}}\left(10-52^{\circ} \mathrm{C}\right)$. The ratio of ${ }^{13} \mathrm{C} /{ }^{12} \mathrm{C}$ in $\mathrm{CO}_{2}$ flux suggested that an increasing proportion of the $\mathrm{CO}_{2}$ emitted at the higher temperatures was geothermally derived. However, in 2016 the highest geothermal source of $\mathrm{CO}_{2}$ had moved and the location was not connected to the highest soil temperature. At that time the maximum $\mathrm{CO}_{2}$ efflux was measured at $44^{\circ} \mathrm{C} \mathrm{T}_{\mathrm{s}}$ warming $(2100 \mathrm{mg}$ $\mathrm{CO}_{2} \mathrm{~m}^{-2} \mathrm{~h}^{-1}$ ), instead of a maximum $65^{\circ} \mathrm{C}$. Our study showed that a significant amount of $\mathrm{CO}_{2}$ emitted from the geothermal temperature gradients can have a non-biotic origin. These abiotic $\mathrm{CO}_{2}$ fluxes have to be considered when interpreting temperature effects on soil respiration rates from geothermal areas or close to active volcanos. The only way to separate the biotic and abiotic $\mathrm{CO}_{2}$ fluxes is by implementing isotope techniques, as done here.
\end{abstract}

Keywords: ${ }^{13} \mathrm{C}$, emission, ForHot, respiration, volcanic soil, warming

\section{YFIRLIT}

Samscetumcelingar leiða i ljós að jarðhitagas getur haft áhrif á mcelda jarðvegsöndun á heitum svceðum á Suðurlandi

Hitastiglar myndast stundum í jarðvegi innan jarðhitasvæða og peir hafa verið notaðir til að rannsaka áhrifhlýnunar á virkni jarðvegsörvera á losun koldíoxíðs $\left(\mathrm{CO}_{2}\right)$ frá yfirborði, sem hefur svo aftur verið tengt væntanlegum áhrifum loftslagsbreytinga á virkni vistkerfa. Рað að jarðfræðilegt $\mathrm{CO}_{2}$ getur einnig afgasast í gegnum berggrunn og jarðveg frá kvikuhólfum á eldvirkum svæðum er minna pekkt meðal vistfræðinga, en par sem slíkt gerist getur pað bjagað mælingar á svörun jarðvegsörvera við hlýnun. Flæði $\mathrm{CO}_{2}$ og hlutfall samsætunnar $\delta^{13} \mathrm{C}$ í pví (sem má nota til að finna hlutfall jarðhitagass) var mælt sumrin 2014 og 2016 frá misheitum skógarjarðvegi á Reykjum í Ölfusi par sem jarðvegshiti á $10 \mathrm{~cm}$ dýpi $\left(\mathrm{T}_{\mathrm{s}}\right)$ var $0-65^{\circ} \mathrm{C}$ hærri en bakgrunns $\mathrm{T}_{\mathrm{s}}$ vegna jarðhitaáhrifa.

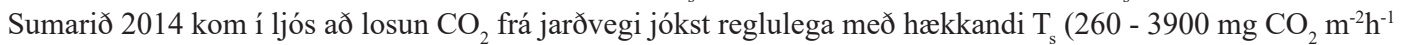
fyrir $10-52^{\circ} \mathrm{C} \mathrm{T}_{\mathrm{s}}$ ). Hlutfall ${ }^{13} \mathrm{C} /{ }^{12} \mathrm{C}$ leiddi enn fremur í ljós að hluti af pessu $\mathrm{CO}_{2}$ var af jarðfræðilegum uppruna og 
petta hlutfall hækkaði með hækkandi $\mathrm{T}_{\mathrm{s}}$. Pegar mælingarnar voru endurteknar sumarið 2016 kom í ljós að stigull jarðfræðilegu $\mathrm{CO}_{2}$ losunarinnar hafði færst til og fylgdi ekki lengur hitastiglinum. Pá var mest losun á $\mathrm{CO}_{2}$ við $44^{\circ} \mathrm{C} \mathrm{T}_{\mathrm{s}}$ hlýnun $\left(2100 \mathrm{mg} \mathrm{CO}_{2} \mathrm{~m}^{-2} \mathrm{~h}^{-1}\right)$, en ekki við hæsta mældu jarðvegshlýnunina, $65^{\circ} \mathrm{C}$. Rannsóknin sýndi pví að pað getur verið vandasamt að túlka vistkerfismælingar á losun $\mathrm{CO}_{2}$ frá jarðhitasvæðum eða í nálægð virkra eldfjalla par sem hluti hennar getur átt sér jarðfræðilegan uppruna. Eina leiðin til að vera viss um að slík áhrif séu ekki til staðar er að gera samtímis samsætumælingar eins og hér var gert.

Lykilorð: ${ }^{13} \mathrm{C}$, eldfjallajörð, ForHot, jarðvegshlýnun, jarðvegsöndun, losun $\mathrm{CO}_{2}$.

\section{INTRODUCTION}

Globally, most of the soil organic carbon is stored at northern latitudes, particularly in the northern permafrost regions and boreal forest soils. Climate warming is almost twice as great in the North compared to the global average during recent decades (IPCC 2013), with a temperature increase of up to $+5{ }^{\circ} \mathrm{C}$ predicted for 2100. Consequently, there is a high risk of increasing the release of soil carbon (C) to the atmosphere in the future due to microbial activity, primarily in the form of carbon dioxide $\left(\mathrm{CO}_{2}\right)$ (Crowther et al. 2016). To study responses of northern ecosystems to climate warming, often experimental approaches are used. Long-term ecosystem manipulations of the temperature are rare because of the logistical and financial challenges of experimental warming at this scale (Kayler et al. 2015, De Boeck et al. 2015). Moreover, warming experiments may be quite artificial, introducing unintended artefacts, e.g. unwanted changes in environmental conditions like humidity, light and wind, as is the case for the frequently used open-top chambers (Chabbi A \& Loescher 2017). All this can be overcome by natural temperature gradients within a short distance, which are available in geothermal areas, for example (O'Gorman et al. 2014). There, the effects of soil warming on the ecosystem can be studied without the confounding effects of manipulative warming and divergent transect approaches (Sigurdsson et al. 2016). Geothermal activity can remain stable for many years, making it possible to investigate long-term warming effects, but major tectonic events can also create new hotspots, exposing previously non-warmed ecosystems to higher temperatures and enabling studying recent (short-term) temperature responses (O'Gorman et al. 2014). Such natural soil temperature gradients can be found, for example, in geothermal systems in south-west Iceland.

The original aim of our study was to investigate changes in $\mathrm{CO}_{2}$ efflux rates along soil temperature gradients to predict the effects of future soil warming on $\mathrm{CO}_{2}$ effluxes. A significant warming will accelerate soil microbial heterotrophic processes, leading to enhanced $\mathrm{CO}_{2}$ effluxes with temperature. The first indirect support for this hypothesis comes from a study by Poeplau et al. (2019) showing a strong warming-induced depletion of carbon concentration in the soils of these geothermal areas. However, soil microbial respiration rates, contrary to the aforementioned hypothesis, were reduced in these warmed soils, as shown in recent laboratory incubation experiments (Marañón-Jiménez et al. 2018), and were most likely due to the reduced carbon content in warmed soils and a subsequent decline in microbial biomass. However, mass-specific respiration rates increased with warming (Walker et al. 2018). Temperature effects on soil respiration are thus highly complex and they need to be studied in the field to fully elucidate the interactions of plants, soil, and climatic variation.

In volcanically active areas it is also known that some geothermal $\mathrm{CO}_{2}$ can be emitted from the underlying volcanic system (Ármansson 2018, Stefánsson 2017, Rey et al. 2015, Fridriksson et al. 2008, Barry et al. 2014, Klusman et al. 2000), which could possibly confound measurements of in situ soil respiration. Geothermal $\mathrm{CO}_{2}$ 
effluxes are receiving a lot of attention in studies on geology and volcanology (Ármansson 2018), but they have not been exhaustively explored in environmental studies aiming at elucidating temperature effects on $\mathrm{CO}_{2}$ efflux rates. Thus, the different source of $\mathrm{CO}_{2}$ might be well known for the volcanology community, but much less for ecologists who are now starting to use geothermal gradients increasingly in climate change studies. To study temperature responses of net ecosystem exchange, ecosystem respiration or soil respiration in geothermal areas, such non-biogenic $\mathrm{CO}_{2}$ effluxes need to be disentangled from biogenic $\mathrm{CO}_{2}$ production. Our first hypothesis was that geothermal $\mathrm{CO}_{2}$ is contributing to overall $\mathrm{CO}_{2}$ emissions at these volcanic sites and possibly having a great impact on the total soil-derived $\mathrm{CO}_{2}$ efflux, and second, that this abiotic flux component increases with the increasing temperature. Since $\mathrm{CO}_{2}$ from biological respiration is isotopically highly distinct from $\mathrm{CO}_{2}$ derived from nonbiotic sources, including geothermal $\mathrm{CO}_{2}$ (e.g. Sano et al. 1985, Caliro et al. 2007, Chiodini et al. 2010, Tassi et al. 2012, Biasi et al. 2008, Rissmann et al. 2012), a stable isotope approach $\left(\delta^{13} \mathrm{C}\right)$ can be used to separate the different flux components. Before geothermal areas are used in studies on effects of temperature increase on soil respiration rates, it is thus necessary to first test whether all $\mathrm{CO}_{2}$ is derived from biological sources or whether abiotic sources exist. The original aim of the study thus shifted to a more methodological study which we found highly necessary and a prerequisite for all future experiments and interpretation of $\mathrm{CO}_{2}$ fluxes. Here, we thus used for the first time a stable isotope approach to separate abiotic from biotic $\mathrm{CO}_{2}$ sources along a geothermal temperature gradient in Iceland. The study was done using the "ForHot" research network (www.forhot. is), which was established in 2011 to bring scientists together to study how changes in soil temperature affect various ecosystem processes (Sigurdsson et al. 2016, Kayler et al. 2015, O’Gorman et al. 2014).

\section{MATERIAL AND METHODS}

Study site

The study site is located in south-west Iceland, near the village of Hveragerði $\left(64.008^{\circ} \mathrm{N}\right.$, $21.178^{\circ} \mathrm{W}$ ), on land owned by the Agricultural University of Iceland. During 2004-2014 the area had a mean annual air temperature of 5.2 ${ }^{\circ} \mathrm{C}$ and a mean annual precipitation of 1431 $\mathrm{mm}$ (Icelandic Met Office 2019). The growing season normally starts in May and ends in late August. The soil type at the study sites is Brown Andosol (Arnalds 2015), with a relatively high $\mathrm{pH}$ (5.5-7.0) and large soil water retention capacity (O'Gorman et al. 2014, Sigurdsson et al. 2016).

On the $29^{\text {th }}$ of May 2008 a major earthquake (magnitude 6.3 on the Richter scale) occurred in south-west Iceland (Halldórsson \& Sigbjörnsson 2009), where typically ca. 70-100 years pass between such large earthquake episodes in this region. The 2008 earthquake caused large structural damage to infrastructures and affected geothermal systems close to the epicentre. One such geothermal system moved from its previous location to a new and previously nonwarmed area (Porbjörnsson et al. 2009), and the new below-ground geothermal channels within the bedrock resulted in soil temperature increases in the soil above. The soil temperature elevation measured at $10 \mathrm{~cm}$ soil depth reached $>50{ }^{\circ} \mathrm{C}$ where the channels are closest to the surface (O'Gorman et al. 2014).

The present study was conducted in an area warmed after the 2008 earthquake during the growing seasons in 2014 and 2016. The site is a mature Sitka spruce (Picea sitchensis) forest, planted in 1966. More information about the site conditions can be found in Sigurdsson et al. (2016).

\section{$\mathrm{CO}_{2}$ efflux measurements with chambers}

The $\mathrm{CO}_{2}$ effluxes were measured using the opaque static chamber method (Maljanen et al. 2017). The measurements were made along the temperature gradient on 10-11 June, 2014 and were repeated on 9-11 July, 2016. The mean air temperature during sampling days was 14 ${ }^{\circ} \mathrm{C}$ in both years; the weather was sunny or 
Table 1. Soil properties in top $0-5$ and $5-10 \mathrm{~cm}$ at the study plots in $2014 / 2016$. Plot names are according to Maljanen et al. (2017) where $\mathrm{FN}+0$ is the non-warmed plot and the value $+\mathrm{X}$ shows the increase in soil temperature at depth of $10 \mathrm{~cm}$ in 2012 when the plots were established. DT = actual difference in soil T compared to ambient soil $\mathrm{T}$ in $2014 / 2016, \mathrm{~T}=$ mean temperature during the gas flux measurements, $\mathrm{GM}=$ gravimetric soil moisture. Note that soil samples were not taken from plot FN+2 in 2016.

\begin{tabular}{|c|c|c|c|c|c|c|c|c|c|}
\hline Plot & DT & $\mathrm{T}\left({ }^{\circ} \mathrm{C}\right)$ & $\mathrm{pH}_{\mathrm{H} 2 \mathrm{O}}$ & $\begin{array}{c}\mathrm{EC} \\
(\mu \mathrm{S} \\
\left.\mathrm{cm}^{-1}\right)\end{array}$ & Tot C (\%) & $\begin{array}{c}\delta^{13} \mathrm{C} \text { in soil } \\
\text { organic } \\
\text { matter }(\% 0)\end{array}$ & N (\%) & $\mathrm{C}: \mathrm{N}$ & $\begin{array}{l}\text { GM } \\
(\%)\end{array}$ \\
\hline \multicolumn{10}{|l|}{$0-5 \mathrm{~cm}$} \\
\hline $\mathrm{FN}+0$ & - & $10.2 / 10.1$ & $5.5 / 5.9$ & $26 / 31$ & $13.4 / 7.8$ & $-28.4 /-27.6$ & $0.61 / 0.48$ & $22.1 / 21.0$ & $131 / 42$ \\
\hline $\mathrm{FN}+1$ & $0.5 / 0.6$ & $10.7 / 10.7$ & $6.0 / 6.4$ & $27 / 20$ & $10.7 / 14.2$ & $-27.9 /-28.9$ & $0.61 / 0.62$ & $17.4 / 26.8$ & $120 / 48$ \\
\hline $\mathrm{FN}+2$ & $1 / \mathrm{nd}$ & $11.2 / \mathrm{nd}$ & $5.8 / \mathrm{nd}$ & $17 /$ nd & $11.0 / \mathrm{nd}$ & $-28.0 / \mathrm{nd}$ & $0.61 / \mathrm{nd}$ & 17.9/nd & $113 / \mathrm{nd}$ \\
\hline $\mathrm{FN}+6$ & $2.4 / 1.2$ & $12.6 / 11.3$ & $5.7 / 6.1$ & $11 / 19$ & $14.5 / 17.3$ & $-28.8 /-28.7$ & $0.71 / 0.80$ & $20.5 / 23.2$ & $168 / 52$ \\
\hline $\mathrm{FN}+10$ & $2.9 / 8.0$ & $13.1 / 18.1$ & $5.8 / 6.0$ & $15 / 36$ & $10.3 / 11.7$ & $-27.7 /-28.3$ & $0.67 / 0.79$ & $15.5 / 17.5$ & $120 / 64$ \\
\hline $\mathrm{FN}+20$ & $5.4 / 39$ & $15.6 / 49.5$ & $5.9 / 5.4$ & $26 / 155$ & $7.6 / 6.0$ & $-28.3 /-28.3$ & $0.57 / 0.49$ & $13.2 / 14.2$ & $120 / 50$ \\
\hline $\mathrm{FN}+40$ & $32 / 53$ & $42.5 / 62.6$ & $6.9 / 5.6$ & $29 / 259$ & $3.4 / 3.8$ & $-27.1 /-27.9$ & $0.40 / 0.34$ & $8.3 / 11.9$ & $62 / 38$ \\
\hline \multicolumn{10}{|l|}{$5-10 \mathrm{~cm}$} \\
\hline $\mathrm{FN}+0$ & - & $10.2 / 10.2$ & $5.7 / 6.1$ & $31 / 32$ & $7.8 / 9.0$ & $-27.1 /-27.9$ & $0.48 / 0.41$ & $16.1 / 19.9$ & $82 / 42$ \\
\hline $\mathrm{FN}+1$ & $0.6 / 0.7$ & $10.8 / 10.9$ & $6.1 / 6.1$ & $25 / 36$ & $5.6 / 6.0$ & $-27.0 /-27.9$ & $0.46 / 0.36$ & $12.2 / 15.9$ & $66 / 41$ \\
\hline $\mathrm{FN}+2$ & $1.1 / \mathrm{nd}$ & $11.3 / \mathrm{nd}$ & $5.6 / \mathrm{nd}$ & $12 / \mathrm{nd}$ & 7.9/nd & $-27.3 / \mathrm{nd}$ & $0.62 / \mathrm{nd}$ & $12.7 / \mathrm{nd}$ & $82 / \mathrm{nd}$ \\
\hline $\mathrm{FN}+6$ & $2.1 / 1.5$ & $12.3 / 11.7$ & $5.9 / 5.8$ & $12 / 34$ & $8.8 / 8.3$ & $-26.7 /-28.0$ & $0.61 / 0.52$ & $14.4 / 9.0$ & $77 / 54$ \\
\hline $\mathrm{FN}+10$ & $2.9 / 8.7$ & $13.1 / 18.9$ & $6.2 / 5.9$ & $10 / 26$ & $7.1 / 7.3$ & $-26.7 /-28.1$ & $0.58 / 0.44$ & $12.4 / 5.1$ & $78 / 64$ \\
\hline $\mathrm{FN}+20$ & $7.7 / 44$ & $17.9 / 54.5$ & $6.1 / 5.8$ & $21 / 69$ & $5.5 / 2.8$ & $-27.0 /-28.0$ & $0.51 / 0.36$ & $10.7 / 12.2$ & $69 / 40$ \\
\hline $\mathrm{FN}+40$ & $42 / 65$ & $52.2 / 75.0$ & $7.0 / 6.7$ & $13 / 66$ & $1.9 / 1.1$ & $-27.9 /-28.3$ & $0.30 / 0.15$ & $6.3 / 8.9$ & $82 / 39$ \\
\hline
\end{tabular}

partly cloudy, no rain episodes. However, soil moisture was higher during the 2014 study than in 2016 (Table 1). Gas fluxes were not measured from all plots due to practical limitations, but a total of six plots were measured each year (Table 1). The sampling plots were located both outside the warmed area and within at different elevated soil temperatures $\left(\mathrm{T}_{\mathrm{s}}\right)$ (Table 1). The plots $(\mathrm{FN}+0, \mathrm{FN}+2, \mathrm{FN}+6, \mathrm{FN}+10$, $\mathrm{FN}+20, \mathrm{FN}+40)$ were named according the warming levels measured in 2012 with site code $\mathrm{FN}$ and temperature elevation as $+\mathrm{X}{ }^{\circ} \mathrm{C}$, as described in an earlier study by Maljanen et al. (2017). The number $(+X)$ indicates soil warming at a depth of $10 \mathrm{~cm}$. No deeper soil temperatures were measured in this study. Due to unexpected changes in the temperature gradient between the years one sampling plot was different in 2014 from that in 2016 (See Table 1). Thus, to better cover the temperature variation, plot $\mathrm{FN}+10$ was measured in 2016 instead of plot $\mathrm{FN}+2$.
Three replicate chambers were used on each measurement plot. The metal flux chambers $(\varnothing=26 \mathrm{~cm}, \mathrm{~h}=30 \mathrm{~cm})$ had a hole in the top for a sampling tube and for a capillary line to avoid any pressure effect. Prior to sampling, the sharp edge at the bottom of the chamber was twisted 3-5 cm into the soil and the top opening was sealed with a rubber septum. Plants were not removed from the soil surface before gas sampling in order to keep the small plots as undisturbed as possible for the other studies within the "ForHot" research network. However, there were no plants in plots $\mathrm{FN}+2$ and $\mathrm{FN}+6$. In plot $\mathrm{FN}+10$ there were no plants in 2014 , but in 2016 vascular plants covered about $30 \%$ of the surface. This was a result of change in soil temperature and the death of trees in that plot. In plot $\mathrm{FN}+20$ there were only mosses and in plot $\mathrm{FN}+40$ all mosses were dead in 2016, whereas in 2014 there were still some living ones. A total of five to six gas samples $(30 \mathrm{ml})$ were collected between 5 to $66 \mathrm{~min}$ after installing 
the sealed chamber. Within $4 \mathrm{~h}$ from sampling, the gas samples were injected into $12 \mathrm{ml}$ Labco pre-evacuated vials (Labco Exetainer ${ }^{\circledR}$ ) for gas analysis at the University of Eastern Finland (UEF). Samples were analysed within two weeks for $\mathrm{CO}_{2}$ concentration and $\delta^{13} \mathrm{C}$ values for $\mathrm{CO}_{2}$. Soil temperatures at 5 and $10 \mathrm{~cm}$ were measured with a manual thermometer and metal probe (YCT, Taiwan) next to the chambers at each sampling time.

\section{Soil gas and hot spring gas sampling}

Concentrations of $\mathrm{CO}_{2}$ in soil gas were measured at the sampling plots simultaneously with the gas flux measurements in June 2014 and July 2016. Gas samples of $20 \mathrm{ml}$ were taken with a stainless steel sampling probe $(\varnothing=3 \mathrm{~mm}, 1=40 \mathrm{~cm})$ at three soil depths, 5, 10 and $20 \mathrm{~cm}$ in 2014 and at depths of 10, 20, 30 and $40 \mathrm{~cm}$ in 2016. Samples of $\mathrm{CO}_{2}$ were treated and analysed as described above. The 2016 samples, but not the 2014 samples, were analyzed for $\delta^{13} \mathrm{C}$ in the soil $\mathrm{CO}_{2}$.

To measure the $\delta^{13} \mathrm{C}$ values of the parent fluid or the abiotic/geothermal source samples were taken on 9 April, 2017, from hot spring vents near the study site (Table 2). An infrared gas analyser (EGM-3) was used to find vents within the ForHot area that had high $\mathrm{CO}_{2}$ concentrations in the steam. Where possible, a chamber (described earlier) was used to isolate hot air rising in the hot spring and air was sucked into the syringe through a hole at the top. Labco Exetainers $\AA$ were emptied two times with a 50 $\mathrm{ml}$ syringe and then filled with a gas sample. During sampling the air temperature was $+2{ }^{\circ} \mathrm{C}$, sunny and wind 2-4 $\mathrm{m} \mathrm{s}^{-1}$ from the $\mathrm{N}$. The soil temperature at $10 \mathrm{~cm}$ in non-warmed soils was $1-2{ }^{\circ} \mathrm{C}$.

Table 2. Measured $\mathrm{CO}_{2}$ concentrations and $\delta^{13} \mathrm{C}$ values of $\mathrm{CO}_{2}$ from two or three replicate samples from hot spring vents near the study site sampled on April 9, 2017. The distance from the study site for each case shown in the table.

\begin{tabular}{llll}
\hline Sample & $\mathrm{CO}_{2}(\mathrm{ppm})$ & $\delta^{13} \mathrm{C}(\%)$ & $1 /$ conc \\
\hline Reykir-drillhole for hot water $400 \mathrm{~m}$ SSW & 891 & -6.52 & 0.00112 \\
& 1177 & -5.28 & 0.00085 \\
\hline Hot spring vent $130 \mathrm{~m}$ SE to forest & 1242 & -5.98 & 0.00080 \\
\hline Hot spring $60 \mathrm{~m}$ NW of forest & 6188 & -5.89 & 0.00016 \\
& 1413 & -6.32 & 0.00071 \\
\hline Hot spring 510 m N of forest & 672 & -7.07 & 0.00149 \\
& 510 & -7.94 & 0.00196 \\
\hline Hot spring 540 m N of forest & 531 & -7.85 & 0.00188 \\
\hline Hot spring 510 m NNW of forest & 725 & -6.45 & 0.00138 \\
& 818 & -6.20 & 0.00122 \\
& 680 & -6.39 & 0.00147 \\
\hline Mean of all samples & 828 & -6.17 & 0.00121 \\
Standard error of mean & 642 & -6.85 & 0.00156 \\
\hline
\end{tabular}


$\mathrm{CO}_{2}$ concentration analysis

Concentrations of $\mathrm{CO}_{2}$ were determined with a gas chromatograph (Agilent 6890N, Agilent Technologies, USA), equipped with an autosampler (Gilson, USA) and thermal conductivity detector (TC). Compressed air, containing $386 \mu \mathrm{l} \mathrm{l}^{-1}$ of $\mathrm{CO}_{2}$, was used for daily calibration. The gas flux rates were calculated from the linear increase or decrease in the gas concentration with time in the headspace of the chamber (Maljanen et al. 2017).

\section{Isotope analysis of $\mathrm{CO}_{2}\left(\delta^{13} \mathrm{CO}_{2}\right)$}

Samples were transported in gas vials by plane within a few days of sampling for all soil and gas analyses, including those for isotope analysis of $\mathrm{CO}_{2}$. Analysis of $\delta^{13} \mathrm{C}$ in $\mathrm{CO}_{2}$ from chamber or soil gas measurements were carried out at UEF. Subsamples $(1 \mathrm{ml})$ were taken from each $12 \mathrm{ml}$ gas vials and were injected into 12 $\mathrm{ml}$ vials filled with $\mathrm{N}_{2}$ and then analysed with a gas chromatography (GC) system coupled to an isotope-ratio mass spectrometer (GC-IRMS) (Delta XPlus; Thermo Finnigan, Bremen, Germany) as described in Biasi et al. (2008). Briefly, $\mathrm{CO}_{2}$ was first concentrated in liquid nitrogen via a precon unit, and then separated on a GC column (Pora Plot Q; $30 \mathrm{~m}$ length). The $\mathrm{CO}_{2}$ was then transferred to the ion source of the IRMS via a Conflow IV interface and open split unit. Helium was used as a carrier gas at a constant flow rate of $1 \mathrm{ml} \mathrm{m^{-1 }}$. The $\delta^{13} \mathrm{C}$ of $\mathrm{CO}_{2}$ samples from hot springs (Table 2) were analysed at the University of Vienna (UNIVIE) by using a headspace gas sampler (Gas-Bench II, Thermo Fisher, Bremen, Germany) coupled to an IRMS (Delta V Advantage, Thermo Fisher, Bremen, Germany).

The results of the $\delta^{13} \mathrm{CO}_{2}$ analysis are expressed as $\delta$ according to the following formula (1):

$$
\delta=\left(\frac{R \text { sample }}{R \text { Standard }}-1\right),
$$

where the $\mathrm{R}$ sample for $\mathrm{C}$ is the ${ }^{13} \mathrm{C} /{ }^{12} \mathrm{C}$ ratio of the sample and the $\mathrm{R}$ standard is the ${ }^{13} \mathrm{C} /{ }^{12} \mathrm{C}$ ratio of Vienna Pee Dee Belemnite (VPDB). The precision of the $\delta^{13} \mathrm{C}$ values was about
$0.20 \%$, respectively, as determined from ten measurements of internal working standards (synthetic air with $300 \mathrm{ppm} \mathrm{CO}_{2}$, Air Liquide, Finland) analysed together with the samples in each run. The absolute accuracy of the analysis was determined by injecting at least three aliquots of calibrated reference gas (99.995 vol.$\%$ purity; Air Liquide, Finland) along with each sample analysis. At both UEF and UNIVIE the reference $\mathrm{CO}_{2}$ gas of the IRMS was regularly calibrated against international calibration standards (IAEA-6, ISO-TOP gas standards (Air Liquide) with certified ${ }^{13} \mathrm{C}$ concentrations) achieving long-term accuracy and precision of the results in both laboratories and ensuring comparable results. Calibration with IAEA6 was done with an elemental analyser (Flash EA 1112 Series, Thermo Finnigan, Bremen, Germany) coupled to the IRMS mentioned above.

\section{Soil and vegetation sampling and analysis}

Soil samples (sampling depths 0-5 cm and 5-10 $\mathrm{cm})$ were collected from all plots in both years (Table 1). Soil pH and electric conductivity (EC) were measured from soil/water slurry $(15 \mathrm{ml}$ soil: $50 \mathrm{ml}$ milliQ- $\mathrm{H}_{2} \mathrm{O}$ ) from homogenized and pooled samples collected with the same warming level. Gravimetric soil moisture was determined by drying the soil for $24 \mathrm{~h}$ at $105{ }^{\circ} \mathrm{C}$. Soil $\mathrm{C}$ and $\mathrm{N}$ contents and $\delta^{13} \mathrm{C}$ values from dried and homogenized samples were determined with the EA-IRMS system at UEF described above. The long-term precision of a quality control standard (wheat) was $<0.15 \%$ ofor $\mathrm{C}$ isotope analysis and $<0.9 \%$ (relative error) for elemental analysis. Isotope results are expressed relative to V-PDB as $\delta^{13} \mathrm{C}_{\mathrm{V}-\mathrm{PDB}}$, as also described above.

Plant samples (Agrostis stolonifera) were picked near the plots, but not exactly from the same place where the gas fluxes were measured because the ground vegetation was scarce. In addition, there were no Agrostis stolonifera or any other grasses growing on plots $\mathrm{FN}+1$ and $\mathrm{FN}+2$. It was also not found on plot $\mathrm{FN}+6$ in 2016 or on plot $\mathrm{FN}+10$ in 2014. Plant samples were also collected outside the warmest plot $\mathrm{FN}+40$ in the area where the trees were already 
dead and also near the coolest plot outside the forest (close to $\mathrm{FN}+0$ ). In addition, samples were collected between the two warmest plots $\mathrm{FN}+20$ and $\mathrm{FN}+40$. After sampling, the leaves of Agrostis stolonifera were dried at $40^{\circ} \mathrm{C}$ for $48 \mathrm{~h}$ and they were ground for the analysis of $\% \mathrm{C}, \% \mathrm{~N}$ and $\delta^{13} \mathrm{C}$, as described above.

\section{Calculation of $\delta^{13} \mathrm{C}$ of sources and isotope mixing model}

The $\delta^{13} \mathrm{C}$ of $\mathrm{CO}_{2}$ emitted from the $\mathrm{FN}$ plots was calculated with the Keeling plot approach (Biasi et al., 2008; Keeling, 1958) using data on $\mathrm{CO}_{2}$ concentration and $\delta^{13} \mathrm{CO}_{2}$ values for each sampling time over the entire chamber closure $(n=6)$. The Keeling plot approach uses a regression on the measured variables $\left(\delta^{13} \mathrm{C}\right.$ and mixing ratios) to determine the end-member isotope value of the excess $\mathrm{CO}_{2}$ relative to the background (air) value (Keeling, 1958). The Keeling plot intercept $\left(\delta^{13} \mathrm{CO}_{2}\right.$ of $\mathrm{CO}_{2}$ respired $)$ was calculated here with Model II (geometric mean) regression (Pataki et al. 2003).

The relative contribution of geothermal vs. biogenic $\mathrm{CO}_{2}$ was calculated with the two-pool isotope mixing model (2):

$$
f=\frac{\delta-\delta_{0}}{\delta_{1}-\delta_{0}}
$$

where $\mathrm{f}$ is the fraction of the geothermal source in overall $\mathrm{CO}_{2}$ emissions, $\delta$ is the $\delta^{13} \mathrm{C}_{\text {of }} \mathrm{CO}_{2}$ of the mixture ( $\mathrm{CO}_{2}$ emitted from FN plots), $\delta_{1}$ is the $\delta^{13} \mathrm{C}$ of the geothermal source, and $\delta_{0}$ is the $\delta^{13} \mathrm{C}$ of biological respiration (Biasi et al. 2008). The $\mathrm{CO}_{2}$ emissions rates from the geothermal source were calculated by multiplying $\mathrm{f}$ by the overall $\mathrm{CO}_{2}$ emission rates, and the biological respiration rates were obtained by the difference between overall and geothermal emissions. To estimate the $\delta^{13} \mathrm{C}$ of the geothermal source, data on $\mathrm{CO}_{2}$ concentration and $\delta{ }^{13} \mathrm{CO}_{2}$ values of the gas samples taken from the hot springs were used (Table 2). Since the $\mathrm{CO}_{2}$ in the soil gas sampled from the hot springs could have been affected by gas mixing between atmospheric and soil gases, we also applied the Keeling plot approach to obtain the $\delta^{13} \mathrm{C}$ of the original source gas (Table 2). We assumed here that $\mathrm{CO}_{2}$ in the hot springs would reflect a mixture of only two sources (atmospheric and geothermal $\mathrm{CO}_{2}$ ). The $\delta^{13} \mathrm{C}$ of biological respiration was represented by a typical end-member value of characteristic C3-type plants (-28\%). This assumption was supported by measured data on $\delta^{13} \mathrm{C}$ values of plants and soil in the study area (see below). Isoerror version 4.1. (Phillips \& Gregg 2001) was used to determine the standard error of $f$, taking into account the standard deviation of the $\delta{ }^{13} \mathrm{C}$ values of the mixture and each contributing source, respectively. A $95 \%$ confidence interval was used to determine whether the $f$ values were significantly different from zero or one, respectively.

We also proceeded to plot Keeling plots and calculated $\delta^{13} \mathrm{C}$ of $\mathrm{CO}_{2}$ from the soil gas depth profiles of the FN plots (e.g. Cerling \& Wang 1996). The Keeling plot assumption was violated here because, due to fractionation during soil gas diffusion, the relation of $\delta^{13} \mathrm{C}$ to the inverse of the $\mathrm{CO}_{2}$ concentration was not linear. However, accounting for this fractionation has been shown to result in an underestimation of $\delta^{13} \mathrm{C}$ of $\mathrm{CO}_{2}$ respiration/emissions (Hahn 2003). We thus refrained from using this correction factor. We used the Keeling plot here merely to evaluate, qualitatively, whether any conclusions can be drawn with regard to sources of $\mathrm{CO}_{2}$ in the soil profile and to compare the isotopic composition of soil gas with that of $\mathrm{CO}_{2}$ emitted from the surface.

\section{Statistical analyses}

Correlations between the gas flux rates, soil variables and $\mathrm{T}_{\mathrm{s}}$ were tested with non-parametric Spearman rank correlation tests (data not normally distributed). (IBM SPSS statistics 25).

\section{RESULTS}

\section{Soil properties}

The measured soil properties from depths of $0-5 \mathrm{~cm}$ and $5-10 \mathrm{~cm}$ are presented in Table 1 . In 2014 soil temperature $\left(T_{s}\right)$ at a depth of $10 \mathrm{~cm}$ increased along the sampling transect up to 50.4 ${ }^{\circ} \mathrm{C}$, whereas in 2016 the maximum temperature of the warmest plot was as high as $75^{\circ} \mathrm{C}$ (Table 1). Thus, soil temperature had increased between 
June 2014 and July 2016 in the warmest plots $(\mathrm{FN}+40, \mathrm{FN}+20)$ but not in the originally cooler plots $(\mathrm{FN}+0, \mathrm{FN}+1, \mathrm{FN}+6)$. Soil moisture was higher in 2014 than in $2016(p<0.001)$ (Table 1).

Soil $\mathrm{pH}$ did not change significantly along the gradient, but soil electric conductivity (EC) was higher in the warmest plots in 2016 but not in the 2014 samples (Table 1). The total C concentration in the soil (Table 1) ranged between 17.3 and $1.1 \%$ and there was a decreasing trend with increasing soil temperature, except that the highest $\mathrm{C}$ concentration was measured from the topsoil of plot $\mathrm{FN}+6$ in 2014. The inorganic C concentration at this site was less than $2 \%$ of the total C (Marañón-Jiménez et al. 2018). Total
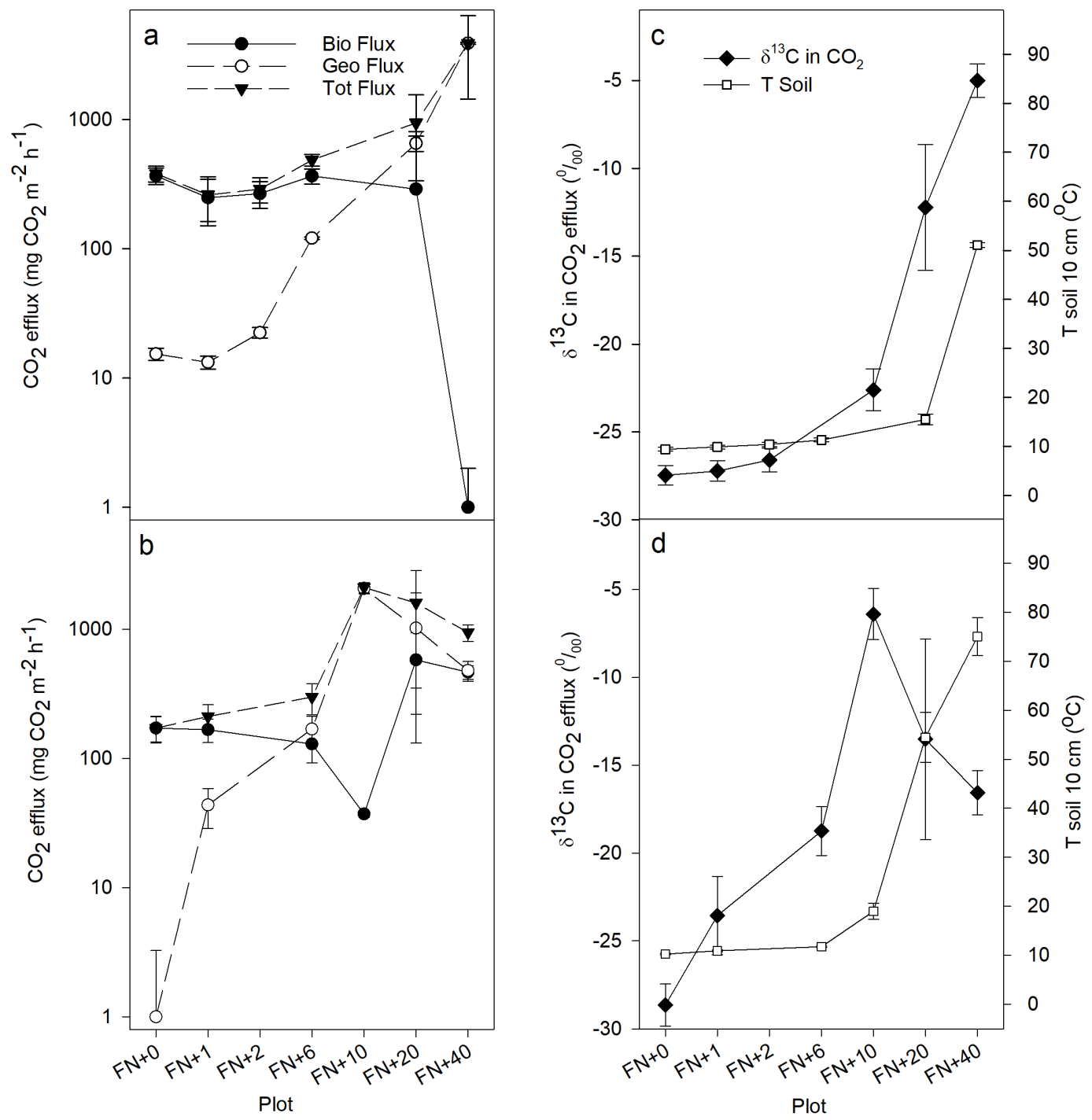

Figure 1. On the left the total $\mathrm{CO}_{2}$ efflux, biological $\mathrm{CO}_{2}$ efflux and geological $\mathrm{CO}_{2}$ efflux in 2014 (a) and 2016 (b). On the right the corresponding $\delta^{13} \mathrm{C}_{\text {in }} \mathrm{CO}_{2}$ efflux values with soil temperature at depth of $10 \mathrm{~cm}$ in 2014 (c) and 2016 (d). Error bars show the standard deviation $(n=3)$. Note the logarithmic scale for $\mathrm{CO}_{2}$ efflux. 
soil $\mathrm{N}$ concentration (range from $0.15-0.80 \%$ ) did not show any clear decreasing or increasing trend with temperature, except the lowest concentrations were measured in the warmest plot $(\mathrm{FN}+40)$. The soil $\mathrm{C} / \mathrm{N}$ ratio in the topsoil $(0-5 \mathrm{~cm})$ varied from 6.3 in the warmest plot $(\mathrm{FN}+40)$ to 26.8 in the slightly warmed plots $(\mathrm{FN}+1)$. The $\delta^{13} \mathrm{C}$ value of the soil organic matter ranged between $-28.91 \%$ and $-26.67 \%$ with no clear trend along the temperature gradient. However, soil organic matter $\delta^{13} \mathrm{C}$ values were more negative in the topsoil (average -28.1\%) than in the 5-10 cm layer (average -27.5\%) ( $p$ $=0.023$ ) (Table 1). There were no significant correlations between soil temperature and soil moisture at the times of sampling.

$\mathrm{CO}_{2}$ efflux and $\delta^{13} \mathrm{C}$ in $\mathrm{CO}_{2}$ of the total $\mathrm{CO}_{2}$ flux Overall $\mathrm{CO}_{2}$ effluxes showed different patterns in the two measurement years. The total $\mathrm{CO}_{2}$ efflux rates $\left(350 \mathrm{mg} \mathrm{CO}_{2} \mathrm{~m}^{-2} \mathrm{~h}^{-1}\right)$ were similar from plots $\mathrm{FN}+0$ up to the soil warming level of $\mathrm{FN}+6$ in 2014, but increased then constantly up to the warmest plot, $\mathrm{FN}+40$, where the total $\mathrm{CO}_{2}$ efflux reached its maximum value (3900 $\mathrm{mg} \mathrm{CO} \mathrm{m}^{-2} \mathrm{~h}^{-1}$ ). In 2016, $\mathrm{CO}_{2}$ effluxes slightly increased with temperature in plots from $\mathrm{FN}+0$ up to $\mathrm{FN}+6$ (from 170 to $300 \mathrm{mg} \mathrm{CO}_{2} \mathrm{~m}^{-2} \mathrm{~h}^{-1}$ ), reached the maximum in plot $\mathrm{FN}+10(2100 \mathrm{mg}$ $\left.\mathrm{CO}_{2} \mathrm{~m}^{-2} \mathrm{~h}^{-1}\right)$, and thereafter decreased in plot $\mathrm{FN}+40$ down to $940 \mathrm{mg} \mathrm{CO}_{2} \mathrm{~m}^{-2} \mathrm{~h}^{-1}$ (Figure 1).

The $\delta^{13} \mathrm{C}$ values of $\mathrm{CO}_{2}$ changed significantly along the temperature gradient and differed also between years (Figure 1). In 2014, similar $\delta{ }^{13} \mathrm{C}$ values were found for gases emitted from $\mathrm{FN}+0$ and $\mathrm{FN}+2$, where soil temperature differed only by ca. $3{ }^{\circ} \mathrm{C}$. However, the $\delta{ }^{13} \mathrm{C} \mathrm{CO}_{2}$ values decreased significantly and progressively by nearly $23 \%$ in $\mathrm{CO}_{2}$ emitted from the warmer plots (from $-27.5 \%$ in $\mathrm{FN}+2$ to $-5.0 \%$ in $\mathrm{FN}+40$ ). In 2016 , the pattern in the observed $\mathrm{CO}_{2} \delta{ }^{13} \mathrm{C}$ values was different; at that time the lowest $\delta^{13} \mathrm{C}$ of $\mathrm{CO}_{2}$ was found in $\mathrm{FN}+10$ plot (-6.4\%o), while the values for $\mathrm{FN}+20$ and $\mathrm{FN}+40$ were higher $(-13.5$ and $-16.6 \%)$, but still significantly different from $\mathrm{FN}+0$ (-28.6\%o). There was also a progressive enrichment in the $\delta^{13} \mathrm{C}$ of

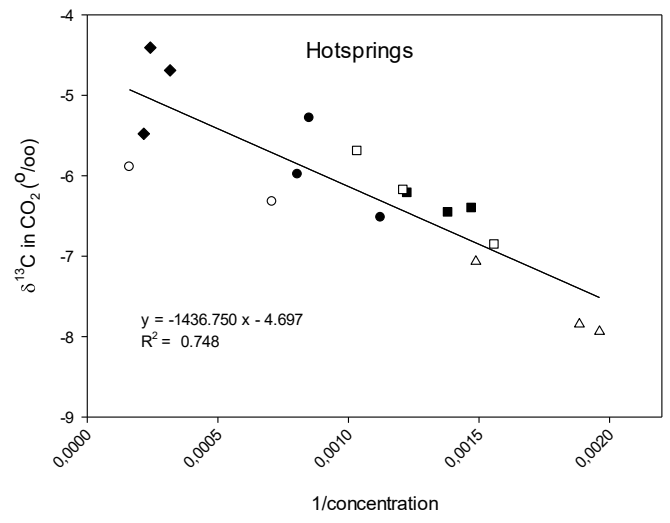

Figure 2. The $\delta^{13} \mathrm{C}$ values of geothermal sources (hot spring vents, data from Table 1) plotted with $1 / \mathrm{CO}_{2}$ concentration. Symbols indicate different sampling sites. The intercept (-4.697) shows the source value for geothermal $\mathrm{CO}_{2}$.

$\mathrm{CO}_{2}$ (from -23.5 to $-18.7 \%$ ) between plots $\mathrm{FN}+1$ and $\mathrm{FN}+6$ in 2016. The $\delta^{13} \mathrm{C}$ signal of the geothermal $\mathrm{CO}_{2}$ measured from the nearby hot spring vents is shown in Table 2 . The $\delta^{13} \mathrm{C}$ geothermal source value calculated using the Keeling plot approach for the geothermal $\mathrm{CO}_{2}$ was $-4.697 \pm 1.23 \%$ o (Figure 2).

\section{$\mathrm{CO}_{2}$ flux components: results of the isotope mixing model}

The absolute amount of $\mathrm{CO}_{2}$ emitted from the different flux components (biological and geothermal) was calculated with the mass balance approach. The estimated geothermal component in the total soil $\mathrm{CO}_{2}$ efflux increased progressively from a few percent (not significantly different from zero in $\mathrm{FN}+0$ ), to almost $100 \%$ in $\mathrm{FN}+40$ in 2014 , with no significant difference between the first three plots (Figure 1). In 2016, the proportion of geothermal $\mathrm{CO}_{2}$ efflux increased progressively from a few percent (but not significantly different from zero percent) in $\mathrm{FN}+0$, to about $30 \%$ in $\mathrm{FN}+1$ to more than $90 \%$ in $\mathrm{FN}+10$, and decreased thereafter down to $60 \%$ in $\mathrm{FN}+40$ (Figure 3), indicating that a spatial shift had taken place in the location of the maximum geothermal flux between the two years. 


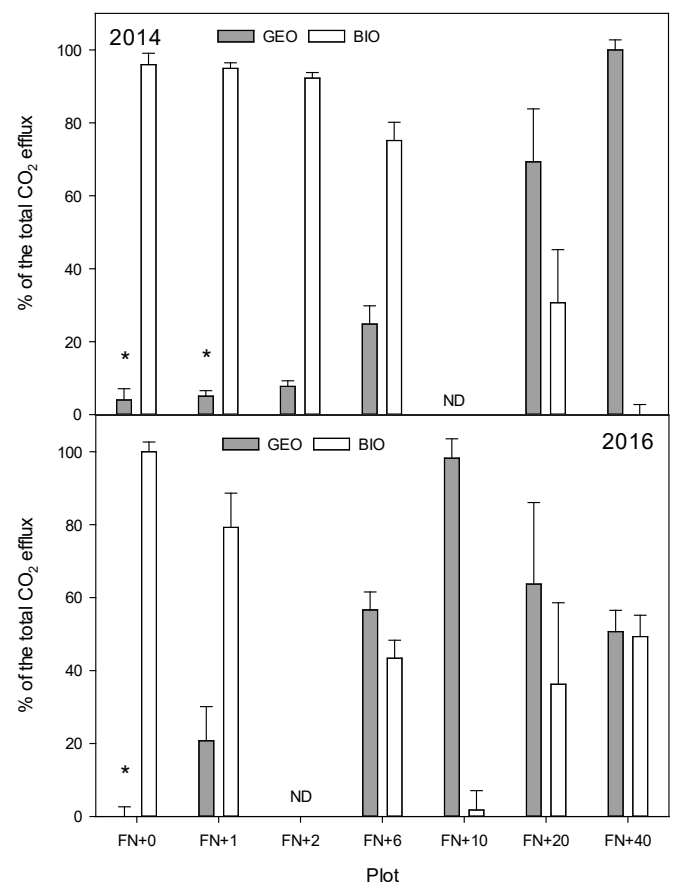

Figure 3. The average ( \pm stdev) $\mathrm{CO}_{2}$ effluxes measured from three replicate chambers from each plot during samplings in July 2014 and June 2016. The bars show the percentage of biological or geothermal origin, based on $\delta^{13} \mathrm{C}$ isotope analysis of emitted $\mathrm{CO}_{2} . \mathrm{ND}=$ the plot was not measured. $*=$ percentage values weree not statistically significant from zero.

In 2014 the biological $\mathrm{CO}_{2}$ efflux rate remained at the same level on the three coolest plots, did not correlate with soil temperature within those plots, and dropped about 70\% in $\mathrm{FN}+20$ plot compared to the coolest plots, and was zero in the warmest $\mathrm{FN}+40$ plot. In 2016 there was a different trend within the research area; the biological $\mathrm{CO}_{2}$ efflux was at a relatively low level, and not significantly different between the sites in the coolest plots, but it further dropped in $\mathrm{F}+10$ plot and thereafter increased again in the warmest plots (Figure 1). In 2014 there was an increasing trend but not a significant correlation with both total $\mathrm{CO}_{2}$ efflux and geological $\mathrm{CO}_{2}$ efflux and soil temperature at a depth of $10 \mathrm{~cm}$. In 2016 there were no linear correlations between total $\mathrm{CO}_{2}$ efflux rates and soil temperatures, again indicating that the spatial shift in geothermal $\mathrm{CO}_{2}$ emission was not mirrored with changes in topsoil temperature.

$\mathrm{CO}_{2}$ concentrations in soil organic matter and $\delta^{13} \mathrm{C}$ in $\mathrm{CO}_{2}$ in the gas phase of soil

Samples for soil gas phase concentrations of $\mathrm{CO}_{2}$, taken from 5,10 and $20 \mathrm{~cm}$ depths in 2014 and from 10, 20, 30 and $40 \mathrm{~cm}$ depths in 2016 differed significantly between plots and increased with depth (Figure 4). In $2014 \mathrm{CO}_{2}$ concentrations also increased with increasing soil temperature and depth and the highest concentrations were measured from the warmest plot FN+40 (up to $180000 \mu 1^{-1}$ ) at a depth of 20 cm (Figure 4). In 2016 the $\mathrm{CO}_{2}$ concentrations from the coolest plot $(\mathrm{FN}+0)$ were similar to those in 2014 (from 1300 to $2200 \mu \mathrm{l} \mathrm{l}^{-1}$ ), but the highest $\mathrm{CO}_{2}$ concentration at a depth of $20 \mathrm{~cm}$ was $70000 \mu \mathrm{l} \mathrm{l}^{-1}$, measured from plot $\mathrm{FN}+10$, and in plots $\mathrm{FN}+20$ and $\mathrm{FN}+40$ still lower (Figure 4). The $\delta^{13} \mathrm{CO}_{2}$ values of soil gas, which were measured only in 2016, also differed significantly between $\mathrm{FN}+0$ and the warmer plots $(\mathrm{FN}+10, \mathrm{FN}+20$ and $\mathrm{FN}+40)$ (Figure 4). In general, changes followed the isotopic signal of $\mathrm{CO}_{2}$ efflux at the surface, with the highest $\delta^{13} \mathrm{CO}_{2}$ of soil air measured at $\mathrm{FN}+10(-6.03 \%)$ and the lowest at $\mathrm{FN}+0(-23.8 \%)$.

\section{Plant samples}

Plant samples collected from the gas sampling plots or close to those were analysed for $\mathrm{C}, \mathrm{N}$ and $\delta^{13} \mathrm{C}$. There was an increasing trend $\left(\mathrm{R}^{2}=0.806, \mathrm{p}=0.006\right)$ in plant tissue $\mathrm{C}$ concentrations with increasing soil temperature (Table 3). The total N concentrations were more variable and there was no significant temperature trend (Table 3 ). A clear difference between plots was found on the $\delta^{13} \mathrm{C}$ values in plant tissue. In the warmest plots, $\mathrm{FN}+20$ and $\mathrm{FN}+40$, the values were less negative than in cooler plots (Figure 5). One outlier from this trend was plot $\mathrm{FN}+10$, which was sampled only in 2016 because in 2014 no Agrostis stolonifera plants were found near the plot. 

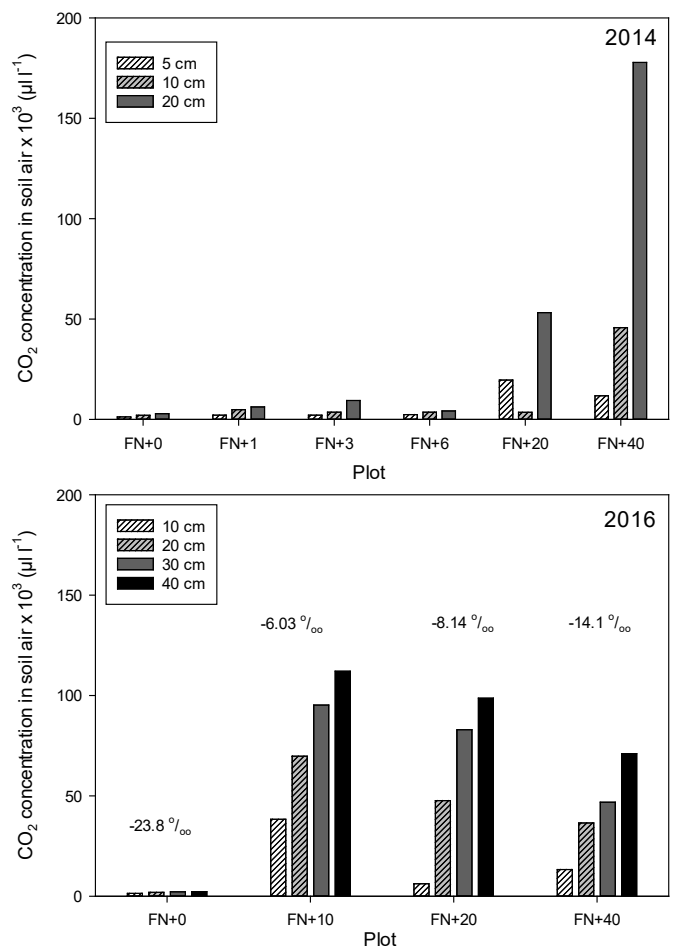

Figure 4. The average $(n=3)$ concentration of $\mathrm{CO}_{2}$ in soil air sampled from depths of 5, 10 and $20 \mathrm{~cm}$ in June 2014 and from depths of 10, 20, 30 and $40 \mathrm{~cm}$ in June 2016 with the corresponding $\delta^{13} \mathrm{C}$ values for $\mathrm{CO}_{2}$ in soil air (mixture of biological and geothermal) calculated with the Keeling plot method. $\delta^{13} \mathrm{C}$ values were not measured in 2014.

Table 3. C and $\mathrm{N}$ content (\%) in grass tissue (Agrostis stolonifera) sampled in June 2016. $\mathrm{FN}+0$ plot is a grassland about $10 \mathrm{~m}$ from the forest edge and plot $\mathrm{FN}+40$ out is about $10 \mathrm{~m}$ downhill from plot $\mathrm{FN}+40$. Soil $\mathrm{T}$ is the soil temperature at a depth of $10 \mathrm{~cm}$ during sampling.

\begin{tabular}{llll}
\hline Plot & Soil $\mathrm{T}\left({ }^{\circ} \mathrm{C}\right)$ & $\mathrm{C} \%$ & $\mathrm{~N} \%$ \\
\hline FN +0 out & 11.0 & 35.8 & 1.98 \\
FN +0 & 10.2 & 37.2 & 2.60 \\
FN +10 & 18.9 & 36.2 & 1.92 \\
FN+20 & 54.5 & 39.9 & 1.60 \\
Between FN +20 & 64.9 & 40.3 & 1.17 \\
and FN+40 & & & \\
FN +40 & 75.0 & 41.0 & 2.10 \\
FN +40 out & 39.6 & 40.6 & 2.39 \\
\hline
\end{tabular}

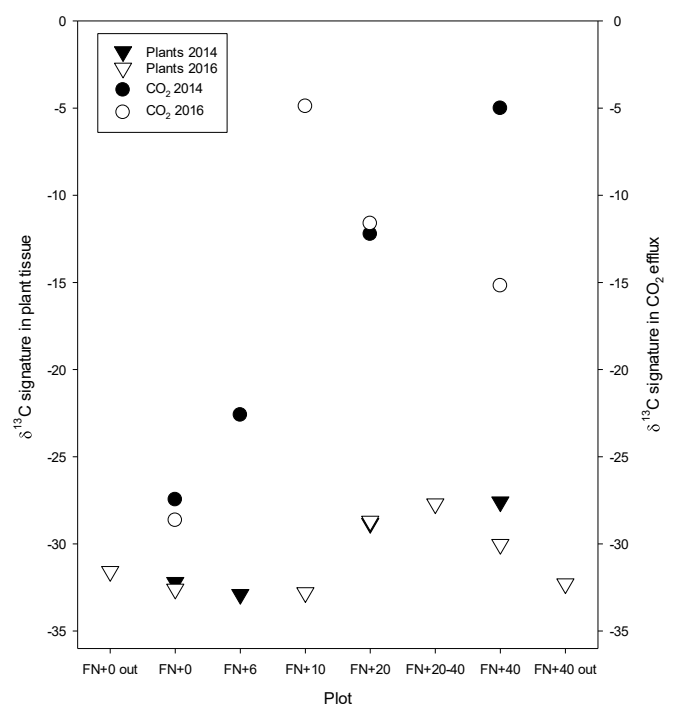

Figure 5. The $\delta^{13} \mathrm{C}$ values in plants collected from the study plots, outside the plots (out) and between $\mathrm{FN}+20$ and $\mathrm{FN}+40(\mathrm{FN}+20-40)$ plots plotted with $\delta^{13} \mathrm{C}$ values in $\mathrm{CO}_{2}$ efflux measured with the chambers and calculated with the Keeling plot approach $(\mathrm{n}=$ 3 ). The plant samples consisted of several leaves of Agrostis stolonifera, which were mixed and pooled before analysis. Note: gas sampling was not done on locations between or outside the plots.

\section{DISCUSSION}

Isotope results show clearly that non-biological $\mathrm{CO}_{2}$ was emitted from the site, especially from the geothermally warmest plots but also, to a variable extent, from the more mildly warmed plots. In 2014 the contribution of geothermal $\mathrm{CO}_{2}$ increased with increasing temperature and the $\mathrm{CO}_{2}$ emitted from the warmest plot $(\mathrm{FN}+40)$ was almost totally geothermal in origin. This highest measured geothermal flux (4 $\mathrm{g} \mathrm{CO}_{2}$ $\mathrm{m}^{-2} \mathrm{~h}^{-1}$ ) was in the range of what Ármannsson (2018) has reported for emissions in geothermal areas in Iceland.

The geothermal emissions were not tightly connected to the warmest topsoil temperatures in 2016. At that time there was also a progressive increase in geothermal $\mathrm{CO}_{2}$ between plots $\mathrm{FN}+0$ and $\mathrm{FN}+10$, corresponding to a $<1$ to 98 $\%$ contribution of geothermal $\mathrm{CO}_{2}$ efflux. The highest proportion of geothermal $\mathrm{CO}_{2}$ efflux at 
that point was not from the hottest plot, where it was only $60 \%$, but from $\mathrm{FN}+10$. The $\mathrm{CO}_{2}$ concentration in soil also showed different trends in 2014 and 2016, as could be seen from the surface $\mathrm{CO}_{2}$ fluxes. The less negative $\delta^{13} \mathrm{C}$ values from the plot $\mathrm{FN}+10$ in 2016 confirmed that the geothermal source was strongest at that point, whereas in 2014 it was strongest in plot $\mathrm{FN}+40$. This da shift in the spatial location of the maximum geothermal source. Geothermal emissions can also occur at low temperatures as a result of emissions from a buried gas reservoir or due to the presence of deep sources of fluids, common with the occurrence of metamorphic processes (Chiodini et al. 2010) and can be of episodic nature. The temporal variability of geothermal $\mathrm{CO}_{2}$ efflux was most likely due to the fact that the geothermal channels had changed, most probably due to a minor earthquake (2.7 on Richter scale) on 8 July, 2015 (Icelandic Met Office, IMO), causing changes in the location of the largest geothermal $\mathrm{CO}_{2}$ source. We noticed that there was a shift also in the higher end of the temperature gradient between the years 2014 and 2016.

Since the outcome of the isotope mixing model is dependent on the isotope values of the end members, the impact and potential uncertainties arising from potentially different isotope signatures of the sources need to be discussed. The $\delta^{13} \mathrm{C}$ values of $\mathrm{CO}_{2}$ from the hot spring vents were in the range of those reported earlier from hydrothermal systems (Sano et al. 1985), though slightly more depleted. Carbon dioxide from volcanic hydrothermal discharge areas usually have $\delta^{13} \mathrm{C}$ values between 0.5 $\%$ and $-2 \%$, especially when the source is of magmatic origin (Tassi et al. 2015). Only when the geothermal gases are characterized by more crustal $\mathrm{CO}_{2}$, can the $\delta^{13} \mathrm{C}$ values also be more negative, down to $-11 \%$ (Tassi et al. 2016). In our case, the $\delta^{13} \mathrm{CO}_{2}$ values were on average ( \pm stdev) $-6.17 \pm 0.94 \%$, and thus a mixture of both sources was likely. There could also have been some variability in isotope signatures of biological source since those can change with temperature, plant cover and $\mathrm{CO}_{2}$ source (Bogue et al. 2019). In our case, the $\delta^{13} \mathrm{C}$ of the Agrostis stolonifera plant increased slightly at the highest temperatures, most likely due to re-assimilation of enriched $\mathrm{CO}_{2}$ stemming from geothermal sources. However, this trend was not noticeable in the soil where the $\delta^{13} \mathrm{C}$ values were relatively constant along the temperature gradient, suggesting only minor impact on biological processes. Generally, due to the large differences in isotope values of the two sources, the results of the isotope mixing model were not very sensitive to changes in the $\delta^{13} \mathrm{C}$ of both end members, and the precision of each source was determined with relatively high confidence.

After subtracting the abiotic proportion of $\mathrm{CO}_{2}$ from the overall $\mathrm{CO}_{2}$ efflux, trends in biotic $\mathrm{CO}_{2}$ effluxes can be discussed. However, temperature trends were difficult to elucidate here, since it was not possible to differentiate heterotrophic respiration from autotrophic respiration in all plots. We are thus merely discussing some observations here. It was, for example, unexpected to see the in situ biological $\mathrm{CO}_{2}$ efflux rates drop to almost zero in the warmest plot $(\mathrm{FN}+40)$ in 2014, which may also have been a result of unfavourable conditions (e.g. high soil $\mathrm{CO}_{2}$ concentration, high temperature) for microbes in soil and therefore changes in microbial population (Oppermann et al. 2010). Unpublished studies on microbial responses at the site have indeed found a shift in the microbial composition at the highest temperatures, though still containing viable bacterial communities (James Weedon \& Erland Baath, personal comm.), and similar results with warming have been found for soil bacteria and fungi in the nearby ForHot grassland sites (Radujkovic et al. 2018). It was noteworthy that in 2016 the lowest biological emissions also shifted and coincided with the highest geological emissions at $\mathrm{FN}+10$, which could have been the results of toxic effects of high geothermal soil $\mathrm{CO}_{2}$ concentrations and possibly other gases in the soil. The warming here was most probably not the only factor affecting biological flux. It has already been shown by Poeplau et al. (2017) that the SOC stock was significantly reduced after 5 years 
of warming. Further, Walker et al. (2018) showed in a laboratory incubation study that the biological $\mathrm{CO}_{2}$ flux was reduced from soil cores taken from warmed plots. However, the low biogenic $\mathrm{CO}_{2}$ efflux rates at the points of the highest outgassing remain unexplained. It is unlikely that the geothermal $\mathrm{CO}_{2}$ had a large impact on the biological flux at lower concentrations, when temperature increase was closer to predictions for climate change until 2100. This study aimed at pinpointing a potentially confounding abiotic $\mathrm{CO}_{2}$ source when studying temperature responses of biological respiration in geothermal gradients, which needs to be accounted for. If the aboveground vegetation can be removed (e.g. in other, less intensively studied plots), the temperature sensitivity of biological respiration can be accurately determined after separating the geothermal source. More studies on this topic are obviously needed for accurate predictions of climate feedback from northern soils.

As mentioned above, the $\delta^{13} \mathrm{C}$ values in the plant samples taken from plots with the strongest geothermal $\mathrm{CO}_{2}$ source in 2014 were moderately more enriched in 2016 than the samples from other plots. This could possibly show that substantial amounts of geothermal $\mathrm{CO}_{2}$ can be taken up by the perennial $A$. stolonifera plants (Oppermann et al. 2010) in the earlier years when the highest outgassing was at $\mathrm{FN}+40$, and these changes in $\delta^{13} \mathrm{C}$ values in plants could be used as an indicator for a strong geothermal source (Bowling et al. 2008, Bogue et al. 2019). It has to be noted that the $\delta^{13} \mathrm{C}$ of plants is generally slightly more negative than that of the soil or soil $\mathrm{CO}_{2}$, due to small (but progressive) discrimination against ${ }^{13} \mathrm{C}$ in heterotrophic respiration (e.g. Boström et al. 2007). The higher $\mathrm{C}$ concentrations in plant tissue with increasing soil temperature were also an interesting finding and there is a need for future research.

\section{CONCLUSION}

This study shows that the geothermal $\mathrm{CO}_{2}$ emission may have a significant role in overall $\mathrm{CO}_{2}$ efflux from geothermal areas and this should be taken into account when measuring net $\mathrm{CO}_{2}$ emissions and planning and conducting isotope experiments on such sites in any volcanic area. Precise partitioning of $\mathrm{CO}_{2}$ efflux between its two main sources is needed in order to get information on the temperature response of in situ biological soil respiration. This is also important for calibrating soil $\mathrm{C}$ models for field $\mathrm{CO}_{2}$ flux rates. There can be a large overestimation of the biogenic $\mathrm{CO}_{2}$ efflux when the corresponding isotopic data are not considered. Source partitioning of $\mathrm{CO}_{2}$ will be critical for field studies; laboratory studies are not impacted by the geothermal $\mathrm{CO}_{2}$ sources from deep-origin (Marañón-Jiménez et al. 2018, Walker et al. 2018, Maljanen et al. 2018).

\section{ACKNOWLEDGEMENTS}

Hanne Vainikainen, Jaana Rissanen, Simo Jokinen and Tatiana Trubnikova are thanked for assisting in the laboratory. Andreas Richter is thanked for the gas analysis at UNIVIE. This work contributes to the COST ES1308 ClimMani, the Nordic CAR-ES and the ForHot (www.forhot. is) network projects and the Icelandic Research Fund project 163272-053. The Icelandic-Finnish Cultural Foundation is thanked for travel grants to MM. We also want to acknowledge the staff at the Reykir campus of the Agricultural University of Iceland for great logistical support. The study was further supported by strategic funding by the University of Eastern Finland (project FiWER granted to $\mathrm{CB}$ ).

\section{REFERENCES}

Ármannsson H 2018. An overview of carbon dioxide emissions from Icelandic geothermal areas. Applied Geochemistry 97, 11-18. doi:10.1016/j.apgeochem.2018.07.013.

Arnalds O 2015. The Soils of Iceland. Springer Netherlands.

Barry PH, Hilton DR, Fueri E, Halldórsson SA, \&

Gronvold, K 2014. Carbon isotope and abundance systematics of Icelandic geothermal gases, fluids and subglacial basalts with implications for mantle plume-related $\mathrm{CO}_{2}$ fluxes. Geohimica et Cosmochimica Acta 134, 74-99.

doi:10.1016/j.gca.2014.02.038, 2014. 
Biasi C, Lind SE, Pekkarinen NM, Huttunen JT, Shurpali NJ, Hyvönen NP, Repo ME, \& Martikainen PJ 2008. Direct experimental evidence for the contribution of lime to $\mathrm{CO}_{2}$ release from managed peat soil. Soil Biology and Biochemistry 40, 2660-2669. doi:10.1016/j.soilbio.2008.07.011.

Bogue RR, Schwandner FM, Fisher JB, Pavlick R, Magney TS, Famiglietti CA, Cawse-Nicholson K, Yadav V, Linick JP, North GB, \& Duarte E 2019. Plant responses to volcanically elevated $\mathrm{CO}_{2}$ in two Costa Rican forests. Biogeosciences 16 , 1343-1360.

doi:10.5194/bg-16-1343-2019.

Bowling DR, Pataki DE \& Randerson JT 2008. Carbon isotopes in terrestrial ecosystem pools and $\mathrm{CO}_{2}$ fluxes. New Phytologist 178, 24-40.

doi: $10.1111 / j .1469-8137.2007 .02342 . x$

Boström B, Comstedt D, \& Ekblad A 2007. Isotope fractionation and ${ }^{13} \mathrm{C}$ enrichment in soil profiles during the decomposition of soil organic matter. Oecologia 153, 89-98.

Caliro S, Chiodini G, Moretti R, Avino R, Granieri D, Russo M, \& Fiebig J 2007. The origin of the fumaroles of La Solfatara (Campi Flegrei, South Italy). Geochimica et Cosmochimica Acta 71, 3040-3055

doi: 10.1016/j.gca.2007.04.007.

Cerling TE \& Wang, Y 1996. Stable carbon and oxygen isotopes in soil $\mathrm{CO}_{2}$ and soil carbonate: Theory, practice, and application to some prairie soils of upper midwestern North America. Pp. 113 131 in T. W. Boutton and S. Yamasaki, editors. Mass Spectrometry in Soils. Marcel Dekker, INC, New York.

Chabbi A \& Loescher HW (Ed.) 2017. Terrestrial Ecosystem Research Infrastructures: Challenges and Opportunities, CRC Press, 534 pp

Chiodini G, Granieri D, Avino R, Caliro S, Costa A, Minopoli C, \& Vilardo G 2010. Non-volcanic $\mathrm{CO}_{2}$ Earth degassing: Case of Mefite d'Ansanto (southern Apennines), Italy. Geophysical Research Letter 37, L11303, doi:10.1029/2010GL042858.

Crowther TW, Todd-Brown KEO, Rowe CW, Wieder WR, Carey JC, Machmuller MB, Snoek BL, Fang S, Zhou G, Allison SD, Blair JM, Bridgham SD, Burton AJ, Carrillo Y, Reich PB,
Clark JS, Classen AT, Dijkstra FA, Elberling B, Emmett BA, Estiarte M, Frey SD, Guo J, Harte J, Jiang L, Johnson BR, Kröel-Dulay G, Larsen KS, Laudon H, Lavallee JM, Luo Y, Lupascu M, Ma LN, Marhan S, Michelsen A, Mohan J, Niu S, Pendall E, Peñuelas J, Pfeifer-Meister L, Poll C, Reinsch L, Reynolds LL, Schmidt IK, Sistla S, Sokol NW, Templer PH, Treseder KK, Welker JM \& Bradford MA 2016. Quantifying global soil carbon losses in response to warming. Nature 540, 104-108. doi:10.1038/nature20150.

De Boeck HJ, Vicca S, Roy J, Nijs I, Milcu A, Kreyling J, Jentsch A, Chabbi A, Campioli M, Callaghan T, Beierkuhnlein C, \& Beier C 2015. Global change experiments: challenges and opportunities. Bioscience 65, 922-931.

doi:10.1093/biosci/biv099.

Fridriksson T, Kristjánsson BR, Ármannsson H, Margrétardóttir E, Ólafsdóttir S \& Chiodini $\mathbf{G}$ 2006. $\mathrm{CO}_{2}$ emissions and heat flow through soil, fumaroles, and steam heated mud pools at the Reykjanes geothermal area, SW Iceland. Applied Geochemistry 21, 1551-1569.

doi:http://dx.doi.org/10.1016/j.apgeochem.2006.04.006.

Hahn V 2003. Soil carbon sequestration and $\mathrm{CO}_{2}$ flux partitioning. isotopic patterns, models, applications. Dissertation, Friedrich-SchillerUniversität Jena, 2003.

Halldórsson $B$ \& Sigbjörnsson $R$ 2009. The Mw6:3 Ölfus earthquake at 15:45 UTC on 29 May 2008 in South Iceland: ICEARRAY strongmotion recordings. Soil Dynamics and Earthquake Engineering 29, 1073-1083. doi:10.1016/j.soildyn.2008.12.006.

Icelandic Met Office 2019. Climatological Data. Icelandic Meteorological Office (Vedurstofa Íslands), Accessed 01.08.2019 https://www.vedur. is/vedur/vedurfar/medaltalstoflur/.

IPCC 2013. Climate Change 2013: The Physical Science Basis. Contribution of Working Group I to the Fifth Assessment Report of the Intergovernmental Panel on Climate Change [Stocker, T.F., D. Qin, G.-K. Plattner, M. Tignor, S. K. Allen, J. Boschung, A. Nauels, Y. Xia, V. Bex and P.M. Midgley (eds.)]. Cambridge University Press, Cambridge, United Kingdom and New York, NY, USA. 
Kayler ZE, De Boeck HJ, Fatichi S, Grünzweig JM, Merbold L, Beier C, McDowell N \& Dukes JS 2015. Experiments to confront the environmental extremes of climate change. Frontiers in Ecology and the Environment 13, 219-225. doi:10.1890/140174.

Keeling CD 1958. The concentration and isotopic abundances of atmospheric carbon dioxide in rural areas. Geochimica et Cosmochimica Acta 13, 322-334. doi:10.1016/0016-7037(58)90033-4.

Klusman RW, Moore JN \& LeRoy MP 2000. Potential for surface gas flux measurements in exploration and surface evaluation of geothermal resources. Geothermics 29, 637-670. doi:10.1016/S0375-6505(00)00036-5.

Maljanen M, Yli-Moijala H, Biasi C, Leblans NIW, De Boeck HJ, Bjarnadóttir B \& Sigurdsson BD 2017. The emissions of nitrous oxide and methane from natural soil temperature gradients in a volcanic area in southwest Iceland. Soil Biology and Biochemistry 109, 70-80. doi:10.1016/j.soilbio.2017.01.021.

Maljanen M, Bhattarai HR, Biasi C \& Sigurdsson BD 2018. The effect of geothermal soil warming on the production of carbon dioxide $\left(\mathrm{CO}_{2}\right)$, methane $\left(\mathrm{CH}_{4}\right)$, nitrous oxide $\left(\mathrm{N}_{2} \mathrm{O}\right)$, nitric oxide $(\mathrm{NO})$ and nitrous acid (HONO) from forest soil in southern Iceland. Icelandic Agricultural Science 31, 11-22. doi:10.16886/IAS.2018.02.

Marañón-Jiménez S, Soong JL, Leblans NIW, Sigurdsson BD, Peñuelas J, Richter A, Asensio D, Fransen E \& Janssens IA 2018. Geothermally warmed soils reveal persistent increases in the respiratory costs of soil microbes contributing to substantial C losses. Biogeochemistry 138, 245-260. doi: $10.1007 / \mathrm{s} 1053$.

O'Gorman E, Benstead JP, Cross WF, Friberg N, Hood JM, Johnson PW, Sigurdsson BD \& Woodward G 2014. Climate change and geothermal ecosystems: natural laboratories, sentinel systems, and future refugia. Global Change Biology 20, 3291-3299. doi:10.1111/gcb.12602.

Oppermann BI, Michaelis W, Blumenberg M, Frerichs JM, Schulz HM, Schippers A, Bueaubien SE \& Krüger M 2010. Soil microbial community changes as a result of long- term exposure to a natural $\mathrm{CO}_{2}$ vent. Geochimica et Cosmochimica Acta 74, 2679-2716.

doi:10.1016/j.gca.2010.02.006.

Pataki DE, Ehleringer JR, Flanagan LB, Yakir D, Bowling DR, Still CJ, Buchmann N, Kaplan JO \& Berry JA 2003. The application and interpretation of Keeling plots in terrestrial carbon cycle research. Global Biogeochemical Cycles, 17. doi: 10.1029/2001GB001850.

Phillips DL \& Gregg JW 2001. Uncertainty in source partitioning using stable isotopes. Oecologia, 127, 171-179. doi:10.1007/s004420000.

Poeplau C, Kätterer T, Leblans NIW \& Sigurdsson BD 2017. Sensitivity of soil carbon fractions and their specific stabilization mechanisms to extreme soil warming in a subarctic grassland. Global Change Biology 23, 977-1360.

doi.org/10.1111/gcb.13491

Poeplau C, Barré P, Cécillon L, Baudin F \& Sigurdsson BD 2019. Changes in the Rock-Eval signature of soil organic carbon upon extreme soil warming and chemical oxidation - A comparison. Geoderma 337, 181-190. doi:10.1016/j.geoderma.2018.09.025.

Radujković D, Verbruggen E, Sigurdsson BD, Leblans NIW, Janssens IA, Vicca S \&Weedon JT 2018. Prolonged exposure does not increase soil microbial community compositional response to warming along geothermal gradients. FEMS Microbiology Ecology.

doi:10.1093/femsec/fix174.

Rey A 2015. Mind the gap: non-biological processes contributing to soil $\mathrm{CO}_{2}$ efflux. Global Change Biology 21, 1752-1761.

doi: $10.1111 / \mathrm{gcb} .12821$.

Rissmann C, Christenson B, Werner C, Leybourne M, Cole J \& Gravley D 2012. Surface heat flow and $\mathrm{CO} 2$ emissions within the Ohaaki hydrothermal field, Taupo Volcanic Zone, New Zealand. Applied Geochemistry 27, 223-239.

doi.org/10.1016/j.apgeochem.2011.10.006.

Sano Y, Urabe A, Wakita H, Chiba H \& Sakai H 1985. Chemical and isotopic compositions of gases in geothermal fluids in Iceland. Geochemical Journal 19, 135-148.

Sigurdsson BD, Leblans NIW, Dauwe S, Guðmundsdóttir E, Gundersen P, Gunnarsdóttir 
GE, Holmstrup M, Ilieva-Makulec K, Kätterer T, Marteinsdóttir B, Maljanen M, Oddsdóttir ES, Ostonen I, Peñuelas J, Poeplau C, Richter A, Sigurðsson P, van Bodegom P, Wallander H, Weedon J \& Janssens I 2016. Geothermal ecosystems as natural climate change experiments: The ForHot research site in Iceland as a case study. Icelandic Agricultural Science 29, 53-71. doi: 10.16886/IAS.2016.05.

Stefánsson A 2017. Gas chemistry of Icelandic thermal fluids. Journal of Volcanology and Geothermal Research 36, 81-94.

doi:10.1016/j.jvolgeores.2017.04.002.

Tassi F, Fiebig J, Vaselli O \& Nocentini M 2012. Origins of methane discharging from volcanichydrothermal, geothermal and cold emissions in Italy. Chemical Geology 310-311, 36-48, doi:10.1016/j.chemgeo.2012.03.018.

Tassi F, Venturi S, Cabassi J, Vaselli O, Gelli I, Cinti D \& Capecchiacci F 2015. Biodegradation of $\mathrm{CO}_{2}, \mathrm{CH}_{4}$ and volatile organic compounds (VOCs) in soil gas from the Vicano-Cimino hydrothermal system (central Italy). Organic Geochemistry 86, $81-93$.

doi:10.1016/j.orggeochem.2015.06.004.

Tassi F, Aguilera F, Benavente O, Paonita A, Chiodini G, Caliro S, Agusto M, Gutierrez F, Capaccioni B, Vaselli O, Caselli A \& Saltori O 2016. Geochemistry of fluid discharges from Peteroa volcano (Argentina-Chile) in 2010-2015: Insights into compositional changes related to the fluid source region(s). Chemical Geology 432, 41-53. doi: 10.1016/j.chemgeo.2016.04.007.

Porbjörnsson D, Sæmundsson K, Kristinsson SG, Kristjánsson BR \& Ágústsson K 2009. Suðurlandsskjálftar 29. maí 2008. Áhrif á grunnvatnsbord, hveravirkni og sprungumyndun [The South Iceland earthquake on $29^{\text {th }}$ of May 2008. Impacts on groundwater levels, activity of geothermal hot-spots and creation of seismic cracks.] Unnið fyrir Orkuveitu Reykjavíkur, ÍSOR2009/028. Iceland Geosurvey, Reykjavik, 42 pp, 2009 (in Icelandic).

Walker TWN, Kaiser C, Strasser F, Herbold CW, Leblans NIW, Woebken D, Janssens IA, Sigurdsson BD \& Richter A 2018. Microbial temperature sensitivity and biomass change explain soil carbon loss with warming. Nature Climate Change 8, 885-889.

doi:10.1038s41558-018-0259.

Manuscript received 9.4.2020

Accepted 9.9.2020 